This item was submitted to Loughborough's Research Repository by the author.

Items in Figshare are protected by copyright, with all rights reserved, unless otherwise indicated.

\title{
Uncovering the desired qualities and behaviours of general practitioners (GPs) during medical (service recovery) encounters
}

PLEASE CITE THE PUBLISHED VERSION

http://dx.doi.org/10.1108/09564231111155097

PUBLISHER

(C) Emerald Group Publishing Limited

VERSION

AM (Accepted Manuscript)

LICENCE

CC BY-NC-ND 4.0

\section{REPOSITORY RECORD}

Gruber, Thorsten, and Fabricio Frugone. 2019. "Uncovering the Desired Qualities and Behaviours of General Practitioners (gps) During Medical (service Recovery) Encounters”. figshare.

https://hdl.handle.net/2134/11918. 
This item was submitted to Loughborough's Institutional Repository (https://dspace.lboro.ac.uk/) by the author and is made available under the following Creative Commons Licence conditions.

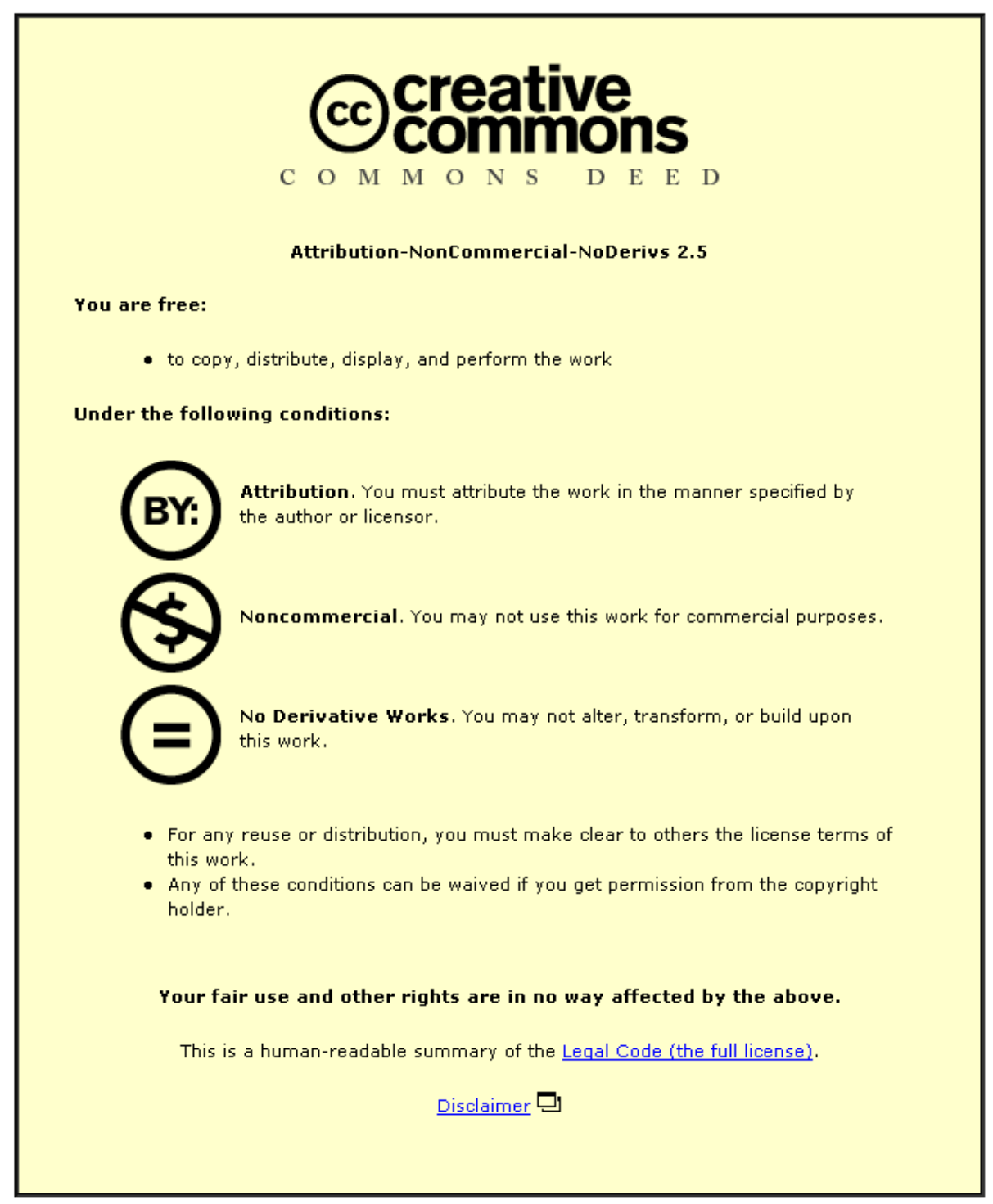

For the full text of this licence, please go to: http://creativecommons.org/licenses/by-nc-nd/2.5/ 


\title{
Uncovering the Desired Qualities and Behaviours of General Practitioners (GPs) during Medical (Service Recovery) Encounters
}

\begin{abstract}
Purpose - The purpose of the study is to uncover the desired qualities and behaviours that patients believe GPs should have in medical (service recovery) encounters. In particular, we try to reveal the qualities and behaviours of GPs that patients value, to understand the underlying benefits that they look for during personal (service recovery) encounters, and to graphically illustrate the findings in a so-called hierarchical value map. This will prove to be important in order to understand patients' needs and desires correctly.
\end{abstract}

Design/Methodology/Approach - An exploratory research study using the qualitative laddering interviewing technique was regarded as appropriate as it allows researchers to gain a deeper insight into an underdeveloped research subject. In total, in-depth laddering interviews with 38 respondents were conducted.

Findings - In case of a service recovery encounter, patients believe that GPs need to show competence, friendliness and empathy in order to restore trust in them. GPs should also listen actively and do the appropriate checks in order to find the root cause of the problem. "Health" was the main value sought by patients. This value is considered by patients to be the gateway to moving on with their everyday lives and search the attainment of other values such as wellbeing, belongingness, accomplishment and self-realization. Moreover, respondents would like to gain knowledge about their disease in order to prevent them in the future and to have some sense of control over the decision of the treatment. Patients also want a more active role in the medical (service recovery) encounter, which calls for a more shared approach by GPs in the interaction with their patients.

Research limitations/implications - Due to the exploratory nature of the study in general and the scope and size of its sample in particular, the findings are tentative in nature. As the study involved patients from one large metropolitan area in the UK, the results cannot be generalized beyond this group.

Practical implications - If GPs know what dissatisfied patients expect, they can adapt their behaviours to their patients' underlying expectations, which should have a positive impact on the evaluation of the doctor-patient relationship. For this purpose, the paper gives recommendations that can help GPs recover patients' trust while at the same time improving their performance in medical (service recovery) encounters.

Originality/value - This paper gives a valuable first insight into the desired qualities and behaviours of GPs during medical (service recovery) encounters. The study results especially indicate that complaining patients are people first and patients second, where the primary importance is the satisfaction of basic social needs. The fact that this study has revealed the highest number of values in published laddering studies so far shows how crucial these medical (service recovery) encounters in general and GP qualities and behaviours in particular are for patients. Another strong contribution of this paper is the finding that all the identified concepts from the laddering interviews that are shown in the hierarchical value maps must not been seen in strict isolation, as in previous research, but have to be understood as a network of interrelated concepts.

Keywords Service Recovery, Doctor-Patient Relationship, Health Services, Laddering Paper Type Research Paper 


\section{Uncovering the Desired Qualities and Behaviours of General Practitioners (GPs) during Medical (Service Recovery) Encounters}

\section{Background - The National Health Service (NHS) in the UK}

The provision of quality health care services has been a demanding task for all Western democracies (John et al., 1998). Technological advances, increased competition, new treatments, rising patient expectations and aging population are some of the factors that have made the health care market become one of the fastest growing service markets in developed and developing economies (Andaleeb, 1998, 2001; O’Connor et al., 2000; Keynote, 2005; WHO, 2008).

In the UK, most of the health care provision comes from the public entity National Health Service (NHS) (Keynote, 2005; John et al., 1998). The NHS is the biggest health service provider and comprises $80.7 \%$ of the total of UK expenditure on healthcare offerings (Keynote, 2005). It delivers healthcare services through two divisions which are the Hospital and Community Health Services (HCHS), which is the division in charge for hospital-based services, and the Family Health Service (FHS), accountable for frontline community-based primary care (this includes General Practitioners (GPs)). The NHS accounts with facilities all over the UK with General Practitioners (GPs) being the gatekeepers of all possible health services needed by patients (John et al., 1998). $75 \%$ of the British population go to the NHS for consultation with the GP at least once a year with women having a higher percentage $(81 \%)$ of usage of this service than men $(69 \%)$ have. It is estimated that there are 300 million consultations with GPs each year in England alone (Keynote, 2005).

Before making policy changes in 1995 with the goal of improving the quality of health services provision in the UK, the government and the NHS received significant criticism: patients had no choice on the kind of treatment and from whom to receive it (Sargeant, 2009). Further, quality and delivery were determined by the NHS based solely on their available resources without taking into consideration all of the patients' needs (Gabbott and Hogg, 
1995; John et al., 1998). Moreover, due to the lack of competition, limited range of choice between providers and the widespread perception that public enterprises offer low quality and bureaucratic services (Dasu and Rao, 1999; John et al., 1998), patient perceptions and expectations of quality in medical service encounters were also low. However, the policy and regulations changes approved in the 90's have reduced the barriers for patients switching to other GPs with the goal of creating internal competition that would result in the enhancement of quality (Gabbott and Hogg, 1995; John et al., 1998).

Given the different consumer-driven policy changes in healthcare (Gabbott and Hogg, 1995; Sargeant, 2009) and the increasing influence of consumerism and knowledge availability on patients' expectations of the GP-patient relationship (Hogg et al., 2004; Laing et al., 2004, 2005a, 2005b, 2009; Newholm et al., 2006), it proves important to explore the doctor-patient relationship in the NHS in more detail. Especially the crucial co-creation role patients have in the development of the treatment and outcome of health services makes it important for doctors to build a relationship with patients and understand their needs, values, and expectations of health service encounters (Hausman, 2004; Laing and Hogg, 2002). The importance of the GPs-patient relationship is furthered by the GPs' need to retain patients and the possible churn outcome when service failure occurs (Gabbott and Hogg, 1995).

In particular, further research is needed on how patients want to be treated if service failures happen as regardless the constant efforts by service providers to give the best value proposition to their customers, the possibility of failure is an issue that is inherent in the nature of services (Homburg and Fuerst, 2005). Service failures occur when the perceived service differs negatively from customers' expectations (i.e. when the predicted service is not delivered) (Zeithaml et al., 1993). After having experienced a service failure, customers should be recovered to a state of satisfaction. Service recovery refers to the efforts taken by services firms in order to amend a problem after a service failure has occurred (Michel, 2001). 
Service providers will use different type of resources, whether economic or psychological, to regain levels of satisfaction of dissatisfied customers (Smith et al., 1999) and retain profitable customers (Michel and Meuter, 2008). However, designing the right service recovery process is a task that most firms have not been able to manage correctly (Johnston and Michel, 2008; Michel et al., 2009).

Thus, in this study, we focus on how patients want to be treated by GPs during normal and service recovery medical encounters. As pointed out by Michel (2001), the comparison between satisfied and dissatisfied customers' perspectives can provide a deeper understanding of the impact of service failures and recovery procedures. Since healthcare is a service in which patients have high emotional involvement (Berry and Bendapudi, 2007; Hogg et al., 2004) and, as such, levels of tolerance by consumers are lower after a service failure (Mattila, 2004), contrasting the differences in the results of both subgroups could be valuable for determining if there are any specifically desired attributes in recovery encounters with the GP.

As discussed by Berry and Bendapudi (2007), the difference between healthcare services and other services and the trust relationship that must be build between physicians and patients require a deeper understanding of the qualities and behaviours desired by patients in the medical (service recovery) encounter. For this purpose, the well-established semistandardized qualitative technique of laddering (Reynolds and Gutman, 1988) will be used to gain an in-depth insight into this important topic. Laddering studies allow researchers to reveal what Gengler et al. (1999, p. 175) refer to as the "reasons behind the reasons". Researchers should then be able to discover information and gain valuable insights into the patients' personal values and basic motivations, which have an impact on their behaviour.

This article proceeds as follows. The paper begins by giving an initial overview of the literature on the characteristics of health services and the doctor-patient relationship. The description of service failure and recovery in health services then leads to the outline of the 
research questions and methodology based on means-end theory. The description of the data analysis method and findings follows from a discussion of the research design. The paper concludes with a discussion of the nature of the constructs and the possible implications the findings have for GPs, health organisations and further research.

\section{Health services: A different type of service}

Health services share several commonalities with other types of services (ie. inseparability, variability, perishability, credence attributes). Health services are for example considered inseparable since patients must be present in order to receive the treatment, procedure or examination (Berry and Bendapudi, 2007). The evaluation of these performances becomes difficult for patients because of the technical complexity that health services have (Laing et al., 2005a; Padma et al., 2009) and their credence attributes, which means that the quality of the service is difficult to determine even after the service has been experienced (Darbi and Karni, 1973).

Healthcare is a one of the most important and personal services that people can consume (Berry and Bendapudi, 2007). It is a service that people require but do not necessarily desire as it is only sought when people are sick, potentially under stress and therefore emotionally involved (Berry and Bendapudi, 2007). Reluctance and dread towards an uncomfortable exam are feelings that affect patients' willingness to perform their role in the service exchange and their perceptions of quality of the service (Berry and Bendapudi, 2007). The patient's cocreation role in health services is important because it is through their detailed and honest description of the symptoms and their compliance with the treatment that the desired outcome can be obtained (Lanseng and Andreassen, 2007; Naidu, 2009).

Furthermore, emotions have an important influence in the quality assessment of healthcare due to the fact that consumers are sensitive to factors affecting their personal health (Moorman and Matulich, 1993). Besides frequently being already stressed when they come to 
see the doctor, patients incur a certain level of risk when receiving healthcare (i.e. when procedures go wrong, they receive the wrong medication or by being exposed to other patients with contagious diseases while sitting in the waiting room) (Taner and Antony, 2006; Wan and Kamazuraman, 2009).

Moreover, health services require high involvement by patients as they relinquish their privacy by discussing personal issues with the healthcare provider that they would not discuss with other service providers (Berry and Bendapudi, 2007; Taner and Antony, 2006). Patients also perceive themselves to be at disadvantage in technical knowledge, which makes them take other factors of the health service encounter into account when assessing the quality of this type of encounter (Gabbott and Hogg, 1996; Taner and Antony, 2006; Wan and Kamazuraman, 2009) such as the doctor's "bedside manner" (Berry and Bendapudi, 2007, p. 113). Therefore, it is important to understand the different aspects of health services that influence patients' expectations and evaluation criteria of these encounters.

\section{The doctor-patient relationship}

The doctor-patient relationship is a crucial element in healthcare (Hensel and Baumgarten, 1988; Hui et al., 2004; Spake and Bishop, 2009). Given the credence attributes inherent in health services, the relationship between the GP and the patient has an important influence on patient emotions and satisfaction even well after the encounter has occurred (Garry, 2007; Michel, 2001).

Furthermore, the complex doctor-patient relationship is affected by diverse factors which are determined through the interaction that takes place in the service encounter (Leventhal, 2008; Spake and Bishop, 2009). Patients' perception of GP competence (experience and knowledge) (Brown and Swartz, 1989; Hensel and Baumgarten, 1988) and patients' level of psychological comfort (Spake et al., 2003) prove to be important factors in the development of trust and commitment of patients towards the GP (Spake and Bishop, 2009). Authors such 
as de Ruyter et al. (1999) found that empathy (i.e. understanding) is the most important attribute in healthcare. Understanding, concern, civility and congeniality shown by the physician to the patient enhance their satisfaction with the relationship and medical encounter (Winsted, 2000). Also, Wilde-Larsson and Larsson (2009) found in a study in Swedish primary care that the combination of competence, good interpersonal interaction of the physician (i.e. information and empathy) and a friendly and private practice atmosphere will contribute to a good quality assessment and patient return intentions.

Moreover, the intimate and very characteristic interpersonal relationship that takes place within health services encounters is going through rapid changes due to increased competition and consumer orientation (Leventhal, 2008). The consumerization of healthcare (Sage, 1991; Laing and Hogg, 2002) and consumers' increasing access to knowledge and education (Laing et al., 2005a) have started to shift the power balance in the GP-patient relationship as patients start perceiving equality with physicians (Laing et al., 2005b). Furthermore, information obtained through the Internet (Laing et al., 2004, 2005b) and online health communities (Hogg et al., 2004) have created the notion of an assumed empowerment in consumers when it comes to professional services such as healthcare (Newholm et al., 2006).

Current research shows that the fragmentation and information empowerment of the healthcare consumer calls for a change in the way patients want the medical service encounter to develop itself (Laing et al., 2009; Laing et al., 2005a). Furthermore, research by Hausman (2004) and Charles et al. (1999) found that patients desire a shift from the usual paternalistic approach (i.e. the doctor has a dominant role and makes the decision on his own) to a more informative and negotiated approach. This means that patients look for a shared model in which they can exchange information with the physician and have a more active role in the treatment decision making (Charles et al., 1997). Further, patients seek to gain psychological comfort (Spake et al., 2003) and feel treated with dignity (Kenny, 1990) in order to have a 
more negotiated process in which the information exchange between patients and GPs can flow naturally (Hult and Lukas, 1995). This in turn will help patients obtain the more personalised and holistic medical attention that they seek (Berry and Bendapudi, 2007). Patients' desire for a shared model is compatible with the service-dominant logic (S-D logic) framework (Vargo and Lusch 2004, 2008abc). S-D logic is a promising new school of thought within marketing. The approach suggests that all companies are service providers with "service" being the fundamental basis of exchange. Vargo and Lusch (2008c) define "service" as the application of operant resources (knowledge and skills) for the benefit of all parties involved in the service exchange. According to S-D logic, companies cannot create value for customers but can only make value propositions and therefore can only create the prerequisites for value (Flint, 2006). Value is always jointly co-created with customers and uniquely and phenomenologically determined by the beneficiary (Vargo and Lusch, 2008c). By contrast, goods dominant logic regards companies as the creators of value and customers as users and/or destroyers of value. Applied to the health context this means that patients desire a shared model where GPs only make value propositions and where patients and GPs jointly create value. This brings along the need of sharing information and to engage in joint problem solving, which relies on mutual trust between both parties in the co-creation process (Vargo, 2008). This shared model should replace the previous paternalistic approach, which resembles the goods-dominant view, with doctors having the leading role making all the decisions.

\section{Service failure and recovery in health services}

Service failures such as for example giving the wrong diagnosis or treatment can test the doctor-patient relationship. These service failures are inevitable due to the nature of services (Homburg and Fuerst, 2005). Bitner et al. (1990) identified 12 categories of incidents within services industries which pertain to three main groups. These groups are known as core 
service failures, which refer to a failure in the main service and service delivery system of the firm; customization failures, which refers to failures in attending special requests and needs from the customer; and unacceptable employee behaviours, which refer to incidents produced due to contact employee behaviour.

Customers may react in different ways after having experienced a service failure. They may decide to either complain to the service provider or a third party, churn (i.e. find a new service provider), engage in negative word of mouth or simply do not take any action at all (Colgate and Norris, 2001; Gutbezahl and Hann, 2006). According to Tax and Brown (1998) and Chebat et al. (2005), considerable evidence suggests that the percentage of dissatisfied customers who decide to complain is low.

In healthcare services, customers are less likely to complain because of the low power that they perceive to have in the relationship (Goodwin and Verhage, 1989). Doctors are perceived as experts and patients become intimidated because of their lack of knowledge and difficulty in assessing this service (Gabbott and Hogg, 1995; Laing and Hogg, 2002). A study by Friele and Sluijs (2006) showed that patients who complain do so mostly for preventing the failure from happening again.

However, it should be in the best interest of any institution to encourage customers to make a complaint because it gives the company an opportunity to redeem itself while obtaining higher levels of customer satisfaction, commitment, loyalty and positive word of mouth (Karande et al., 2007; Swanson and Kelley, 2001; Tax and Brown, 1998). For health service organisations, service recovery may save costs and increase loyalty and positive word of mouth of patients (Schweikhart et al., 1993). Service recovery, however, does not only involve complaint handling, but also refers to all immediate efforts in response to a service failure (Groenroos, 1988; Michel, 2001). These efforts can be implemented to avert and 
resolve service failures before customers decide to either leave dissatisfied (without complaining) or complain (Lewis and Spyrakopoulos, 2001).

In addition, research elaborated by McCollough and Bharadwaj (1992) proposed the theory of the service recovery paradox. This theory proposes that customers who have gone through a successful service recovery have higher levels of satisfaction and repurchase intention than in the case of not having experienced a service failure at all. However, subsequent and current research (McCollough et al., 2000; Magnini et al., 2007; Michel and Meuter, 2008) have shown that the service recovery paradox is not a common event and only occurs when the customer perceives that the service failure is neither critical nor the service provider's responsibility.

\section{Evaluating medical service recovery encounters}

When evaluating the service recovery encounter, customers' satisfaction will be determined by the perceived fairness of the new exchange process (de Ruyter and Wetzels, 2000a; Tax and Brown, 1998). Tax and Brown (1998) and Tax et al. (1998) proposed that customers use three dimensions of justice to determine their satisfaction with the service recovery encounter. These dimensions concern the fairness of the actions they have to carry out to gain compensation (i.e. procedural justice); the interaction and treatment received from the contact-employee (i.e. interactional justice); and the received compensation for the failure (i.e. outcome justice).

In a health service recovery context, Dasu and Rao (1999) identified that patients use two types of expectations when facing these encounters. These are will expectations, which are their predictions of what the hospital will do to manage the complaint; and should expectations, which are the customers' ideal resolution of the problem. Furthermore, Mattila and Cranage (2005) identified informational justice as a fourth dimension influencing satisfaction with service recovery. They argued that consumers reduce attributions of blame to 
the service provider if they receive accurate information and choices. As a result, consumers perceive that they have more control over the outcome of the encounter (Mattila and Cranage, 2005).

Consequently, Friele and Sluijs (2006) found that an improvement in the system will satisfy patients' sense of justice. They also showed that a fair and respectful treatment, physicians' assumption of responsibility, an explanation of what happened, an apology and an effort by the physician to restore the doctor-patient relationship are part of complainants' expectations within the service recovery encounter in health services. Patients expect responsiveness and an explanation, and they have also low expectations of service recovery efforts provided by public-hospitals because they regard them as bureaucratic and complex entities (Dasu and Rao, 1999; Gutbezahl and Haan, 2006).

In addition, Priluck and Lala (2009) suggest that compensation after a service failure should be determined by contact employees and varied according to the different levels of expectations that customers have after a service failure. Conversely, Wirtz and Mattila (2004) argue that compensation may neither alleviate the effects of a poor recovery effort nor increase the levels of satisfaction when a good recovery process has taken place. Likewise, Friele and Sluijs (2006) found that only a small percentage of complainants in healthcare (7\%) complain in order to get compensation.

Moreover, courtesy, empathy and quick reaction to service failure are among customers' requirements for a successful service recovery encounter (Hocutt et al., 2006). Emotions will also influence the perceptions of the outcome in service recovery encounters (Varela-Neira $e t$ $a l ., 2008)$. As Berry and Bendapudi (2007) explained, patients are in dread when going to the medical encounter. After a service failure, negative emotions will influence complainants' perceived justice and evaluation of the recovery efforts (Varela-Neira et al, 2008). Severt et al. (2008) proposed that a hospitality centric philosophy can improve patients' experience in a 
hospital setting while diminishing their emotions of fear and stress. They further argued that this experience improvement through hospitality practices may help patients regain their health. Moreover, research by Ashill et al. (2005) showed that service recovery performance within a public hospital setting will be positively affected by the empowerment that frontline staff have; the presence of an effective teamwork environment; clear information and guidelines for employees to perform their role in the encounter; and the level of affective commitment that staff have towards the hospital.

Rod and Ashill (2009) found that employees' service recovery performance will be positively influenced by the job resourcefulness trait of contact employees, the amount of received training they have and the rewards that they may obtain for good recovery efforts. In contrast, healthcare hospital staff may perceive service recovery efforts as an extra-role activity that would distract them from their regular tasks, for which they need to be really focused due to the inherent high risk and technical difficulty involved in the performance (Gutzebahl and Haan, 2006).

\section{Research objectives}

A review of the literature has established that the desired attributes and behaviours that patients would like their GPs to have during medical (service recovery) encounters have not been addressed in depth. There is further a lack of research focusing on the benefits that the attributes and behaviours of GPs create for patients during medical (service recovery) encounters.

The objectives of this research are therefore: The first objective will be to uncover and understand the desired qualities and behaviours that patients believe GPs should have in medical (service recovery) encounters. It is important to understand patients' needs and desires in order to obtain a valuable in-depth insight into what consumers consider as important attributes in the GP-patient interaction. As mentioned by Olson and Reynolds 
(2001), uncovering the desired attributes that customers want in a product or service is the first step in order to understand the reasons why consumers make decisions. Subsequently, this will then result in recommendations that can help GPs recover patients' trust while at the same time improving the performance in service recovery encounters (Berry and Bendapudi, 2007). For this purpose, we will obtain attribute-consequence-value chains (A-C-V) using means-end theory in order to develop a Hierarchical Value Map (HVM) of the attributes and needs desired by patients. This will help to illustrate the qualities and behaviours of GPs that patients value in a medical (service recovery) context by showing a map of interconnected concepts (Grunert et al., 2001). The illustration will help see how different concepts are related to each other and the amount and strength of linkages between them (Bryman and Bell, 2007).

The second objective will be to reveal the benefits sought by patients in a medical (service recovery) encounter. As benefits are the reasons why a certain attribute is important (Olson and Reynolds, 2001), it becomes of significance to elicit and understand the different consequences sought by patients and how these benefits further connect to different values. Through this, the elements that determine patients' behaviour can be understood and used to determine a better way for motivating patients to take their part in their co-creation role during service recovery encounters (Berry and Bendapudi, 2007).

Answering these questions will further the health services literature, satisfy the need to understand patients' traits, circumstances, needs, and desired attributes in service recovery encounters; and uncover possible marketing implications that can help GPs in order to maintain patient loyalty and improve the performance in service recovery encounters (Berry and Bendapudi, 2007). 


\section{Methodology - Using the laddering technique to investigate GP qualities and behaviours}

For this exploratory research study the semi-standardized qualitative laddering interviewing technique (Reynolds and Gutman, 1988) was regarded as an appropriate research method as it allows researchers to gain a deeper insight into an under-developed research subject. Using laddering, researchers are able to examine the consumer's individuality in depth while still producing quantifiable results. Laddering is especially useful for understanding qualities and behaviours and for exploring individuals' opinions, attitudes and beliefs (Veludo-de-Oliveira et al., 2006). Laddering usually involves personal semi-standardized in-depth interviews where interviewees are given the possibility to express freely and answer questions in their own words (Olson and Reynolds, 2001). The technique bases its approach on means-end theory, which Grunert et al. (2001, p. 63) describe as "one of the most promising developments in consumer research since the 1980s". The theory states that values or desirable end-states are the key drivers of consumers' choice patterns (Gutman, 1982). In other words, the attributes of products or services ("means") represent means to achieve more important desired consequences, which in turn are other means to achieve an ultimate value (“ends") (Olson and Reynolds, 2001). In this research we suggest that the ability of a patient to attain his personal goals and values (ends) depends to a certain degree on the qualities and behaviours of GPs (means) during medical (service recovery) encounters.

Since its development, the laddering technique has been used in marketing studies of a variety of consumer goods, brands and services (Veludo-de-Oliveira, 2006). Recently, laddering has been used successfully in domains such as relationship marketing (Paul et al., 2009), sales management (Deeter-Schmelz et al., 2002, 2008), business-to-business relationships (Henneberg et al., 2009), services marketing (Gruber et al., 2009ab; Gruber et al., 2006), and higher education (Voss et al., 2007). 
During the laddering process interviewers ask probing questions to reveal structural relationships between attributes, consequences provided by those attributes, and personal values or goals that the consequences reinforce. For this purpose, interviewers repeatedly ask: "Why is attribute/ consequence/value xyz important to you?", with the answer to this question serving as the starting point for further questioning. The aim of the sequence of probing questions is to identify cognitive relationships of personal relevance to the respondent (Gengler and Reynolds, 1995). For higher level consequences and values, Reynolds et al. (2001) suggest that interviewers should also ask questions such as "How does that make you feel?"

\section{Data collection}

Sample size and sampling technique

Reynolds et al. (2001) suggest that approximately 20 respondents per subgroup can provide researchers with sufficient data to gain significant understanding of the main desired attributes, consequences and values of products, services or people. Thus, 20 interviews were conducted among respondents who had experienced a service recovery encounter with their GP in the UK while 18 interviews were conducted among respondents who had a normal encounter (i.e. no service failure experienced). Snowball sampling, which consists of asking recruited respondents to refer subsequent participants that share the characteristics desired for the research (Malhotra and Birks, 2006), was used to identify respondents. This nonprobability sampling technique, which has been used successfully in similar service research recently (Groth et al., 2009), allowed us to gain access to more respondents who shared the sought characteristics for the subgroups of this study. 


\section{Sample characteristics}

Most respondents were postgraduate students, with an average age of 30.1 years for the normal encounters subgroup and 25.4 years for the recovery encounters group.

We tried to maintain balance between the genders of respondents in order to avoid bias in the overall results due to gender differences in value preferences (Rokeach, 1973). Therefore, the gender distribution across subgroups was of 11 female and 9 male respondents for the service recovery encounters and of 7 female and 11 male respondents for normal medical encounters with the GP.

\section{Combining CIT and laddering}

The critical incident technique (CIT) (Flanagan, 1954) was used as a "warm up" technique before the actual laddering interviews started. The idea behind this procedure was to establish rapport with respondents by showing them that we were genuinely interested in their personal experiences and to prepare them for the following laddering interviews. During the CIT phase of the interview, respondents were asked to recall the most recent encounter with their GPs (either normal or failure/recovery encounters) experienced within the last twelve months. The focus on the last 12 months was necessary to avoid or reduce biases and mistakes in the responses and description of encounters due to the passage of time since the encounter (Gremler, 2004; Ramsaran-Fowdar, 2008). Typical service failures mentioned by respondents of the recovery subgroup were: GP did not ask thoroughly about patient symptoms and gave the wrong diagnosis; GP was not able to diagnose the patient's problem and gave the wrong or ineffective treatment; GP showed indifference and lack of interest during the interaction.

After that we asked respondents to elicit the qualities and behaviours (attributes) that they would expect their GP to have in either (a) a normal or (b) a service recovery encounter. In case respondents elicited 5 or more attributes, they were asked to rank them in order of importance so that we were able to start the laddering phase of the interview with the most 
important attributes (Reynolds and Gutman, 1988; Deeter-Schmelz, 2002, 2008). After this, variations of the question "why is it important to you?" were used with the purpose of helping respondents elaborate and uncover the underlying consequences and values behind a certain mentioned attribute (Reynolds and Gutman, 1988). This process was repeated until the respondents either reached the value level or was unable to give further answers. The interviews lasted between 15 and 78 minutes (40.34 minutes average) in total.

\section{Data analysis}

Once the information was obtained from the interviews, content analysis was conducted in order to extract "chunks of meaning” (Gruber et al., 2006, p. 627) for the development of meaningful categories (Reynolds and Gutman, 1988). The laddering data were then classified into attributes, consequences and values and later entered into the LADDERMAP software (Gengler and Reynolds, 1993) for further analysis. The following tables give an overall view of the 12 attributes, 18 consequences and 10 values elicited the most often by both subgroups together with a brief description of each construct and the number of times the concepts were mentioned in the ladders by each subgroup.

Insert Tables 1-3 about here

Table 4 shows that a total of 375 ladders were collected from the laddering interviews and the 38 respondents provided between 5 and 26 ladders each, with an average of 9.9 ladders per respondent. The longest ladder consisted of 10 concepts of meaning (attributes, consequences, and values) and the shortest 3, with an average of 5.7 .

Insert Table 4 about here 
By comparison, previous laddering studies by Gruber et al. (2009b) and Voss et al. (2007), collected on average fewer (5.6 and 4.3) and also shorter (2.9 and 4.8) ladders per respondent.

After generating summary codes, the LADDERMAP software was used for building implication matrices for each subgroup. These matrices show the amount of direct and indirect links that a certain element has with another (Deeter-Schmelz et al., 2002, 2008, Reynolds and Gutman, 1988). While direct relationships among concepts are the times one attribute or consequence is connected directly to another attribute or consequence, indirect relationships are the times one attribute or consequence is connected to another concept but with another element in between (Gruber et al., 2006; Reynolds and Gutman, 1988).

Next, a so-called Hierarchical Value Map (HVM) was build for each subgroup with the data from the corresponding implication matrices. HVMs illustrate the most important concepts of meaning in a graphical form for further interpretation. For this purpose, researchers have to decide on a suitable cut-off level. For example, a cut-off level of 1 means that every connection between constructs mentioned by respondents is graphically represented. The resulting HVM is "a mass of links and concepts that usually is unintelligible" (Christensen and Olson 2002, p. 484). The higher the chosen cut-off level is, the more linkages and constructs of meaning will disappear and the more interpretable the map will become. However, if the cut-off level is too high, too many constructs will have disappeared and the resulting map will not be interesting. Researchers, therefore, have to find a balance between data reduction and retention (Gengler et al., 1995) and between detail and interpretability (Christensen and Olson 2002) to create a clear and expressive map with sufficient information. A cut-off level of three was determined as most suitable as it provided us with the most important information from the data set while reaching a balance between data reduction and retention. This cut-off level means that the linkages between elements must have been elicited by at least three respondents in order to be shown in the HVM. 


\section{Results}

The HVM in Figure 1 shows a very complex map formed by patients as they try to reach the desired outcome of getting healthy in a medical service recovery encounter.

Insert Figure 1 about here

In service recovery encounters, patients want their GPs to show empathy, be professional and friendly, have good communication skills, and be competent in order to build trust in their abilities and willingness to help patients. GPs can also build trust with patients (although not directly) by showing empathy. By perceiving that GPs show interest and understanding ("empathy"), patients feel that they are being taken seriously. This process builds trust in the doctor-patient relationship. Once patients feel that they can trust the doctor, a sense of comfort and feeling of being cared for can be observed.

The feeling of relief or comfort, which respondents obtain mostly by developing trust in the physician, is also directly influenced by the accessibility patients have to the GP after a service failure has occurred. Furthermore, the attributes of responsibility, professional behaviour and active listening influence this consequence indirectly. This suggests that after a service failure, patients want their GPs to acknowledge and take responsibility of the complaint in order to feel that their problem is taken seriously. By listening actively to patients, doing checks and following professional behaviour, patients also believe that GPs will determine the right diagnosis. These consequences ("take problem seriously" and “diagnosed correctly") influence the patient' relief of stress and worry.

After examining the linkages between elements elicited by respondents, it seems that the sense of comfort and trust in the physicians helps patients to open up about their illness and take their part in the co-creation of the effective treatment that GPs would determine. Furthermore, the consequence "feel cared for" has a strong influence on reaching an effective 
treatment. In this regard, the consequence "effective treatment" is one of the main benefits sought by patients in this type of encounters. Due to the fact that most of the service failures elicited by respondents were core service failures, the respondents' main concern in the service recovery encounter was getting an "effective treatment" in order to solve their medical problems. Thus, we decided to name this consequence "effective treatment" as it was the solution that was mostly elicited by respondents. For administrative service failures (e.g.: non availability of patients' records, wrong appointment settings, etc.), we created the code "get solution". However, only 2 respondents experienced this type of failure and hence, this construct was not mentioned enough times to appear in the HVM.

Furthermore, "feeling cared for" (direct influence), "open up" (direct influence) and "feeling comfortable" (indirect influence) are the main consequences that lead to receiving the effective treatment which in turn will result in the attainment of health. Health is the main value or end state sought by patients when requiring health services (Gabbott and Hogg, 1995, 1996; Laing and Hogg, 2002; Lytle and Mokwa, 1992). Even though the map shows a strong link between effective treatment and health, the latter is also perceived to be obtainable through the prevention of illnesses ("prevent"), "feeling understood" and a "negotiated process" between GPs and patients during medical service recovery encounters. When GPs are informative, patients gain knowledge which will help in the development of an effective treatment and in the prevention of future illnesses.

Effective treatment also leads to patients "not wasting time" in coming back to the doctor again. This will give patients the opportunity to "move on" to achieve their goals in life ("accomplishment") and to feel safe ("safety") since they perceive that they are in good hands and not at risk of catching further diseases while waiting for medical attention.

The value of "health" leads to the attainment of different values as patients perceive that they need their health in order to move on and go back to their normal lives. This implies 
going back to family and social life ("belongingness") but it also leads to the sense of feeling good and having a long life ("well-being"). The latter will in turn lead to going back to work, study and achieve goals (“accomplishment"). Through the achievement of goals, people feel that they can fulfil all their dreams and needs ("self-realization") and also enjoy life ("hedonism"). Moreover, the HVM for the recovery subgroup suggests that patients want to feel that their complaint makes a contribution to society and avoids others to go through the same ("altruism"). If GPs demonstrate "responsibility", patients will perceive that their complaints are helping to "improve the system". As patients feel that they help others, they feel better about themselves ("self-esteem") as well.

Insert Figure 2 about here

The HVM for the normal medical encounter subgroup portrayed in Figure 2 shows a map, which can be interpreted more straightforwardly. The most important attributes for patients in a normal medical encounter with a GP are competence, friendliness, being informative, and empathy. These attributes are important to patients for them to feel comfortable with the doctor and to feel understood. Especially "friendliness" has a strong link with the consequence "feel comfortable".

Furthermore, the main consequences for this subgroup are "feel comfortable", "trust", “open up", "effective treatment", "feel cared for", "feel understood" and "diagnosed correctly". These follow an order before reaching the value of "health". Once patients feel comfortable, they gain confidence and trust in the GP's abilities, which will lead to them opening up and expressing themselves freely about their condition. This has a strong link to getting the right diagnose which will lead to the benefit of an effective treatment. The latter has the strongest link to the "health" value. 
By showing empathy towards their patients, GPs can make their patients feel understood, which also helps them express themselves (“open up"). As a consequence of this, patients get the sense of feeling cared for and that someone is there for them, relieving them from worry and dread and making them feel safe ("safety"). Moreover, "feel cared for" has also a strong link with "health" as respondents mentioned that once they feel cared for, they believe that they will get healthy.

Just as for the recovery subgroup, health is also a gateway for patients in order to move on with their lives and satisfy other needs or values. Once health is achieved, patients feel that they can go back to their families and social lives ("belongingness"). Furthermore, they also feel good and that believe they will have a long life ("well-being"). This will, in turn, make them feel better about themselves ("self-esteem") and go back to the pursuit and achievement of goals ("accomplishment"). The latter succession of values helps respondents in getting the best out of life ("self-realization"). However, some respondents of the normal encounter subgroup feel that they can reach satisfaction once they get what they expect from the medical encounter with the GP. They reach this end state through "feeling treated as individuals".

\section{Discussion}

The presented findings suggest a very complex view that patients have of medical (service recovery) encounters with GPs. Not surprisingly, receiving an effective treatment with the consequence of getting healthy is at the centre of patient desires. This coincides with previous research by Gabott and Hogg (1996) and Laing and Hogg (2002), which suggest that a good core service outcome is the most essential consequence sought by patients.

However, due to the credence attributes of this type of service, patients have difficulties in assessing the competence of doctors and the technical quality of the outcome (Padma et al., 2009). Hence, they will look for signs of interactional quality in order to assess the competence of GPs and to develop trust in their abilities and the outcome of the encounter 
(Hausman, 2004; Reidenbach and Sandifer-Smallwood, 1990). The concepts depicted in both HVMs for normal and service recovery encounters suggest that it is mostly through interpersonal interaction attributes and behaviours of GPs that patients develop trust and a sense of comfort within the medical (service recovery) encounter. In order to understand how patients perceive a doctor to be competent, we asked respondents how they would identify this characteristic. Most respondents answered that GPs would give this impression by being informative, speaking about their experience and background, having a confidence tone of voice and by listening carefully.

Other interpersonal interaction attributes such as friendliness, empathy, and professional behaviour also influence the building of trust between doctors and patients. As Brown and Swartz (1989) and Spake and Bishop (2009) point out, the interaction has a significant impact on patients' quality perceptions in this type of service. The findings of our study are also consistent with research by Hausman (2004) which evaluates the influence of interpersonal relationships on the outcome of encounters and the motivation of patients to follow the treatment provided by the doctor. As Chenet et al. (2000) and Mattila (2004) found, trust is one of the key elements in order to evaluate service performance and reduce perceived risk in services. Interestingly, the findings of this research contest findings by Shemwell et al. (1994) which showed that trust did not significantly moderate perceived risk in primary care. Our research findings, however, suggest that once trust in the physician is developed by patients, the latter are more willing to open up and discuss freely the details of their problems. This, in turn, will help GPs to make the right diagnosis, give the right information (health advice and/or feedback) and develop the effective treatment needed in order for patients to regain their health. As data by Laing and Hogg (2002) also suggest, the usage of interpersonal and process of delivery quality for assessing health services is different than in other professional services (e.g. legal and finance services) in the emotional involvement by patients in 
developing the confidence ("trust") that doctors have the right knowledge and their best interest at heart. On the other hand, the desired outcome "Health" is perceived by the respondents as being the gateway or requirement in order to move on with the achievement of other values and goals in their lives. Consequently with Maslow's (1970) hierarchy of needs and theory of motivation, health is part of the physiological needs and is considered as a starting point in the satisfaction of needs by individuals. Patients perceive that once they regain their health they can go on with the different activities of their everyday life.

Furthermore, respondents also want to satisfy their safety needs. The empathy looked for in a doctor is an antecedent to the development of rapport and feeling understood (Macintosh, 2009). For the respondents of this study, this bond helps them to open up, feel like at home and cared for (Paul et al., 2009). This sensation is linked to a feeling of being in safe hands, secured and protected, which satisfies the safety needs of the individuals (Maslow, 1970).

Our findings also corroborate previous research by Gabbott and Hogg (1996) and Padma et al. (2009) that showed that the attainment of health is a feature that is expected by patients and is usually taken for granted. If present, the interactional quality will be the main influence on satisfaction with these encounters (Brown and Swartz, 1989). However, if it is not present good interpersonal quality won't be able to redeem the failure (Gabbott and Hogg, 1996). Previous research by Jayanti and Whipple (2008) showed that the likeability of the physician had an impact on patients' satisfaction or dissatisfaction with the encounter. They found that physicians that were perceived to be more likeable by patients had poorer ratings than nonlikeable physicians in cases of failure. In this research, the HVM for the normal subgroup shows that the end state of satisfaction is present as a consequence of being treated as individuals. As a result of opening up and trust, which are consequences of the interaction and competence of the GP, patients feel treated as individuals who are at the same level as the physician. 
Nevertheless, patients look for more attributes and benefits in the GP-patient encounter after experiencing a service failure. This may be due to the fact that the zone of tolerance of individuals varies according to situational factors (Zeithaml et al., 1993) and narrows after a service failure (Hoffman, 1995; Weun et al., 2004). In health care, the complexity of the needs desired by patients and the level of importance attached to having health in life make the zone of tolerance smaller for this type of service in comparison to other services industries (Taner and Antony, 2006). Moreover, the high level of emotional involvement, trust and affective commitment inherent in health services (Berry and Bendapudi, 2007; Hogg et al., 2004; Mattila, 2004) also reduces customers' levels of tolerance for service failure in this type of encounters (Mattila, 2004). Given the fact that the likability of the physician will impact the perceptions of overall quality in case of a service failure within health services (Jayanti and Whipple, 2008), patients may look for more attributes and benefits from the interaction with the physician in order to regain trust, which is important for the continuation of the relationship (Shemwell et al., 1994). Thus, the findings of this research support the result by Mattila (2004) who showed that recovery efforts in these types of circumstances - services with high emotional involvement, affective commitment and trust - should be higher as customers expect more in the case of service failures.

Our findings also show that competence has a stronger role in the building of trust in the recovery encounters than in normal medical encounters. This is similar to what Jayanti and Whipple (2008) implied in their research as patients would be willing to trade off likeability for competence in the healthcare setting. These findings seem to partly concur with the conclusions given by Friele and Slujis (2006). In agreement to their findings, the HVM for the recovery subgroup shows that patients want to feel that the handling of their complaint will improve the system in order to avoid it from happening to someone else. Friele and Sluijs (2006) also found that only a minority of the complainants in a hospital setting will look for 
financial compensation in case of a service failure. Similarly, none of the complainants in our study seemed to be interested in a financial retribution. Instead, complaining patients were mostly concerned with getting the right diagnosis and effective treatment, which, in turn, are antecedents to regaining health.

Furthermore, patients also look for the consequence "treated as individual", by which respondents' referred to being treated fairly, like an individual and at the same level as the physician. This consequence can be considered to be part of the construct of perceived interpersonal fairness that is sought by individuals during the service recovery encounter (Tax et al., 1998). The attributes elicited as antecedents of this consequence are part of the elements identified by Tax and Brown (1998) in the provision of interactional justice.

Moreover, patients in this study expect their GPs to act professionally by doing the necessary checks and following a proper conduct and ethic. They also expect them to take responsibility, be accessible and provide with a "negotiated process" during the encounter. These elements can be considered as part of the procedural justice construct described by Tax and Brown (1998), Tax et al. (1998) and Colquitt (2001). Regardless of not being mentioned as an end states or values sought by patients, the presence of attributes like taking responsibility (Tax and Brown, 1998), accessibility, proper checks and procedures conducted (Tax et al., 1998) and the sought consequence of having a voice in and influence on the outcome (Colquitt, 2001) imply the presence of procedural justice.

Another noteworthy finding of this research is the presence of the constructs "gain knowledge" and "negotiated process". Gaining knowledge through health advice and feedback from the physician seem important to patients in both types of encounters since they give patients a sense of control and help them prevent illness and stay healthy. The sense of control and the perception of having received proper feedback about their condition can be 
interpreted as part of the elements that provide individuals with informational fairness (Colquitt, 2001; Mattila and Cranage, 2005).

Additionally, some patients want to feel that finding an effective treatment is an outcome of a negotiated process with the doctor. The presence of the latter and the feeling that they take an active part in the decision have an impact on patients' self-esteem. Conversely, the findings seem to point out a fragmentation in the way patients want the medical service encounter to develop itself (Laing et al., 2009; Laing et al., 2005a). On the one hand, patients appear to want to gain and exchange knowledge with the doctor by having a negotiated process and compare the information with the one that they already have (Newholm et al., 2006). On the other hand, the majority of patients still want the doctor to know more and come up with the final interpretation of the information and decision on the effective treatment to follow (Laing et al., 2004; Laing and Hogg, 2002).

Our research findings also show the influence that the consumerization of healthcare (Sage, 1991), the empowerment of consumers through the gain of knowledge (Laing et al., 2005a) and the need to feel treated with dignity and as an individual (Kenny, 1990) have on the growing need of patients to get a different and more negotiated approach rather than the paternalistic model in this type of service encounter (Charles et al., 1999; Hausman, 2004; Laing et al., 2005b; Newholm et al., 2006). By getting patients to "feel understood" and "treated as individuals", GPs may provide the psychological comfort and well-being according to the patients' needs (Spake et al., 2003). This in turn, will help the information flow between the patient and the GP (Hult and Lukas, 1995) and provide the holistic attention sought by patients (Berry and Bendapudi, 2007).

Finally, the importance given to the accessibility of the GP by respondents (especially in service recovery encounters) suggests that the encounter is assessed holistically. Factors like the waiting periods and the ease of contact of the GP, which are apart from the interaction of 
the encounter, have an influence on both the outcome of the encounter and patients' satisfaction (e.g. Gabbott and Hogg, 1996). Our study shows that the attribute "accessible" appears to have an influence in the sense of comfort that respondents desire to obtain and hence, will also influence the development and outcome of the medical encounter.

\section{Summary of findings and possible implications for GPs and health organisations}

The research findings present the qualities and behaviours of GPs that patients desire in medical (service recovery) encounters. These comprise a complex and broad set of attributes which produce a series of consequences sought by patients in order to regain trust, comfort and ultimately their health. GPs should especially work on different aspects of their behaviours for enhancing the interactional quality of the encounter. As the HVMs for the normal and recovery subgroup show, interactional quality is important in order to achieve the effective treatment or solution.

In case of a service recovery encounter, respondents believe that GPs need to show competence, friendliness and empathy in order to restore trust in them. As mentioned, GPs can give patients the impression of being competent by speaking about their experience and background, having a confidence tone of voice and by listening carefully to what their patients have to say. As listening is a skill, it can be learned, taught, enhanced and evaluated (de Ruyter and Wetzels, 2000b; Ramsey and Sohi, 1997). GPs could improve their listening skills by using the following training activities: GPs should be trained to improve their capability to analyse messages and interpret their correct meanings. Therefore, they have to increase their knowledge base by including scripts and cues to their repertoire. For GPs to be able to respond better to patients, they have to enhance their verbal communication skills and to improve their patience and adaptability. GPs can learn all these skills through role-playing and several other training tools. They should train their active listening skills throughout their career and not only during the initial training period. 
GPs are also expected to show interest in and understanding (empathy) of their patients' problems and be friendly and courteous to them. GPs can display the appropriate and demanded emotions by practicing 'emotional labour' (Ashforth and Humphrey, 1993). GPs can practice emotional labour either through surface acting or deep acting. Surface acting means that they pretend to have certain emotions, which they do not truly feel, by displaying certain desired facial expressions, voice tones, or gestures (Ashforth and Humphrey, 1993). Recent research by Groth et al. (2009), however, showed that customers can identify feigned emotions to a certain degree, which makes surface acting a problematic strategy. The recognition of faked emotions will then negatively influence customer perceptions as they will not believe that the employee is sincerely interested in them and their problems and they will not feel taken seriously. By practicing deep acting, GPs may sincerely try to change their emotions so that they can play their role successfully. They can either try to evoke (or conceal) certain emotions or use thoughts and images to elicit certain emotions. GPs cannot engage in deep acting during the medical (service recovery) encounter but they could still try to change their emotions and genuinely feel what the patients demand them to feel before the encounter takes place. For example, if they are in a bad mood they could spend some time on actively invoking "thoughts, images, and memories to induce the associated emotion (thinking of a wedding to feel happy)" (Ashforth and Humphrey, 1993, p. 93). GPs can also take part in empathy training or use perspective taking techniques (Groth et al., 2009). Perspective taking is a cognitive skill that allows individuals to understand another individual's point of view (Davis, 1980). Research by Parker and Axtell (2001) has revealed that perspective taking is positively associated with patience, reasonableness, and sensitivity.

GPs should also do the proper checks by following a respectful and ethical professional behaviour in order to find the root of the problem. Furthermore, respondents want their GPs to take responsibility for the problem and give a justification of what happened. Even though it 
is not likely to get a proper admission of medical mistakes due to legal barriers (Friele and Slujils, 2006), an explanation of what happened and acknowledgement of patients' condition will give patients the impression of being taken seriously. This will improve the quality of the interaction during the encounter. In the case of an administrative mistake, the acknowledgement of wrongdoing and taking of corrective measures will give the patient the sensation of making an improvement in the system. This sensation and the perceived responsiveness will impact on customers' assessment of the encounter (Hocutt et al., 2006; Mattila and Cranage, 2005; Williams et al., 1995) and satisfy respondents' desire to help others and contribute to society (Friele and Slujils, 2006).

Moreover, respondents would like to gain knowledge about diseases in order to prevent them from happening again. GPs could help patients in this regard by providing them with leaflets, reading lists, website addresses or by getting them in contact with self-help groups if necessary. Patients also desire to have some sense of control over the decision of the treatment and a more active role in the encounter and treatment, which calls for a shared model in the process of treatment decision making (Charles et al., 1999). Through this type of approach, a two way interaction in which patients and physicians exchange information and discuss all aspects that are relevant for the decision-making occurs (Charles et al., 1997; 1999). Thus, patients will feel that they have a more active role in the encounter and that the decision is made together with the physician (Charles et al., 1997).

Patients' desire for better accessibility and shorter waiting times calls for management to find ways to improve access. In order to do this, management should also consider that respondents desire GPs to take time to listen to them, not be dismissive and inform them of their condition. Therefore, shortening time for the GP-patient encounter is not a suitable solution. Time is an important resource for GPs to obtain a favourable outcome and reestablish the relationship with the patient. Especially when GPs want to make a diagnosis they 
should follow the good practice set by the Mayo clinic and take whatever time is needed to collect all the required information to avoid rushing to conclusions that could later endanger the patient's health (Berry and Seltman, 2008).

As previous research by Rod and Ashil (2009) has shown, the increase of job resources is important in order to avoid burnout in employees and improve service recovery performance. Therefore, the design of special customer service and interaction training programmes can be a possibility to improve physicians' performance in the medical (service recovery) encounter with patients. By enhancing their interpersonal abilities, physicians can make better use of the time they have with patients. Even though some doctors may be reluctant to have such training programmes (Laing and Hogg, 2002), analysis and explanations of its benefits should be provided in order to prevent GPs from thinking that these programmes would only be a distraction from their core responsibilities.

Additionally, patients' views should be taken into consideration when developing benchmarking processes and improvements. Previous research by Guven-Uslu (2005) revealed that patients' expectations in the UK were not considered in this process. Therefore, listening to patients' feedback is of importance as it makes them feel that their problems are being taken seriously and that they are contributing to the improvement of the system.

\section{Limitations and directions for further research}

Like all research studies, this project has several limitations as well. First, even though we aimed at recording information in an unbiased manner, we are aware of the fact that there is, always the possibility of interviewer bias when conducting personal interviews. We have therefore tried to minimise personal leanings and not influence respondents to give a hopedfor answer.

Second, the study only involved respondents from one large metropolitan area in the UK, which means that the results cannot be generalized beyond this group. However, it also has to 
be said that the potential for generalizability can never be achieved in any one study, but is an empirical question that requires comparisons over different studies (Greenberg, 1987). Thus, what is now needed is similar research with different sample populations. Results from these studies could then be compared and differences and similarities revealed.

Most interviewees were in the age group of 21 to 38 (only two respondents were older), which would classify them as young to middle aged patients. According to Drain (2001), age has an influence on the assessment of quality in the primary care medical encounter since young patients are more judgemental of the quality of the interaction. Previous research by Gabbott and Hogg (1995) also identified other clusters (e.g. women with family and the elderly) having different expectations and assessment of medical encounters. As age, gender and socioeconomic factors are characteristics that influence quality appraisals of healthcare services (Padma et al., 2009; Kemppainen et al., 1998), further research should find out if these variables have an impact on the qualities and behaviours of GPs that patients desire during medical (service recovery) encounters.

Hierarchical value maps also only display associations beyond a specific cut-off level, which means that associations have to be mentioned by a certain number of respondents in order to be graphically represented. However, as neither theoretical nor statistical criteria exist that help researchers decide which cut-off level they should choose (Grunert and Grunert, 1995), further research might try to develop these criteria.

Further research could also investigate whether patient expectations differ greatly from what GPs believe patients want. In this connection, Bitner et al. (2000) suggest that service providers may not always know their customers' service quality expectations. Similarly, Mattila and Enz (2002) revealed a large gap between customer and employee perceptions regarding service quality expectations. In a health care context, Fottler et al. (2006) and Wisniewski and Wisniewski (2005) suggest the existence of a gap between the patients' and 
staff's perceptions of reliability attributes and actual service delivery. Further, physicians perceive patients' expectations to be lower than they really are (O'Connor et al., 1994; O' Connor et al., 2000). Consequently, fellow researchers could interview both GPs and their patients. The resulting hierarchical value maps could highlight different views and compare patients' and GPs' perception of the service recovery process. Insights gained could make GPs aware of differing perceptions and identify areas for training. GPs could also use hierarchical value maps to segment patients and to tailor behavioural strategies to different patient groups.

\section{Conclusion}

This paper gives a valuable first insight into the desired qualities and behaviours of GPs during medical (service recovery) encounters. Our findings show that laddering provides researchers with a research design, which unlocks means-end considerations otherwise hidden from quantitative research. Several concepts that are known from the literature such as "trust", "competence" and "effective treatment" were identified and their importance was reinforced. Although earlier service recovery research in other service industries have arrived at similar findings, few have attempted to examine what lies behind the attributes of "Empathy", "Competence" and "Friendliness" that customers ask for and the values customers want to reinforce through the service experience. In the context of health care, GPs can leverage this information to enhance the GP-patient relationship and to foster positive patient outcomes.

Our study results also stress the fact that complaining patients are people first and patients second, where the primary importance is the satisfaction of basic social needs. Even though the importance of social needs has been known in the (service) literature for quite some time (e.g. Schneider and Bowen, 1995), many service providers, unfortunately, still do not seem to pay sufficient attention to this important issue. We hope that our study helps raising awareness for the social nature of service exchanges. 
The fact that this study has revealed a very high number of very long ladders and also the highest number of values in published laddering studies so far shows how emotionally involved respondents are when it comes to discussing health related issues. In particular, our results show how crucial medical (service recovery) encounters in general and GP qualities and behaviours in particular are for patients. Due to the high importance of health, patients want to have the feeling of control during medical (service recovery) encounters and especially want to be integrated in the service provision. Therefore, GPs need to understand that patients do not only want to be provided directly with a solution, but they want to be involved as active players in the decision-making process. According to S-D logic, the ability to share information hereby relies on mutual trust between the parties and is essential for the co-creation process (Vargo, 2008).

Another strong contribution of this paper is the finding that all the identified concepts from the laddering interviews that are shown in the hierarchical value maps must not been seen in strict isolation, as in previous research, but have to be understood as a network of interrelated concepts: GPs can improve service recovery activities their by not just having the appropriate attributes desired by patients, but by assessing these in a way that their impact is linked to the perception of the patient to the important consequences and motives. Laddering helps GPs understand that their attributes have several important consequences for patients (e.g. the feeling of being taken seriously), which are then linked to patients' personal values and basic motivations (e.g. perceptions of justice). By using methods such as the laddering interviewing technique, researchers can reveal how all these indentified elements that are of importance to patients are interconnected and interdependent, which then helps health service providers realise that focusing on concepts (e.g. GPs being competent or friendly or empathetic) in isolation is not sufficient for recovering dissatisfied patients in face-to-face medical (service recovery) encounters. 


\section{References}

Andaleeb, S. (2001), "Service quality perceptions and patient satisfaction: a study of hospitals in a developing country", Social Science \& Medicine, Vol. 52 No. 9, pp. $1359-1370$.

Andaleeb, S. (1998), "Determinants of customer satisfaction with hospitals: a managerial model", International Journal of Health Care Quality Assurance, Vol. 11 No. 6, pp. 181 187.

Ashforth, B. E. and Humphrey, R. H. (1993), "Emotional labor in service roles: the influence of identity", Academy of Management Review, Vol. 18 No. 1, pp. 88-115.

Ashill, N., Carruthers, J. and Krisjanous, J. (2005), “Antecedents and outcomes of service recovery performance in a public health-care environment", Journal of Services Marketing, Vol. 19 No. 5, pp. 293 - 308.

Berry, L. L. and Bendapudi, N. (2007), "Health care: a fertile field for service research", Journal of Service Research, Vol. 10 No. 2, pp. 111 - 122.

Berry, L. L. and Seltman, K. (2008), Management Lessons from Mayo Clinic: Inside One of the World's Most Admired Service Organizations, McGraw-Hill, New York, NY.

Bitner, M., Booms, B. and Tetreault, M. (1990), "The service encounter: diagnosing favorable and unfavorable incidents", Journal of Marketing, Vol. 54 No. 1, pp. 71 - 84.

Bitner, M. J., Brown, S. W. and Meuter, M. L. (2000), "Technology infusion in service encounters", Journal of the Academy of Marketing Science, Vol. 28 No. 1, pp. 138-149.

Brown, S. and Swartz, T. (1989), "A gap analysis of professional service quality", Journal of Marketing, Vol. 53 No. 2, pp. 92 - 98 .

Bryman, A. and Bell, E. (2007), Business Research Methods, 2nd Edition, Oxford University Press, Oxford.

Charles, C., Gafni, A. and Whelan, T. (1999), "Decision-making in the physician-patient encounter: revisiting the shared treatment decision-making model”, Social Science \&Medicine, Vol. 49 No. 5, pp. $651-661$.

Charles, C., Gafni, A., Whelan, T., (1997), "Shared decision-making in the medical encounter: what does it mean? (Or, it takes at least two to tango)", Social Science \& Medicine, Vol. 44 No. 5, pp. $681-692$.

Chebat, J., Davidow, M. and Codjovi, I. (2005), "Silent voices: why some dissatisfied customers fail to complain", Journal of Service Research, Vol. 7 No. 4, pp. 328 - 342. 
Chenet, P., Tynan, C. and Money, A. (2000), "The service performance gap: testing the redeveloped causal model", European Journal of Marketing, Vol. 34 No. 3/4, pp. 472 495.

Christensen, G. L. and Olson, J. C. (2002), "Mapping consumers' mental models with ZMET”, Psychology and Marketing, Vol. 19 No. 6, pp. 477-502.

Colgate, M. and M. Norris (2001), "Developing a comprehensive picture of service failure", International Journal of Service Industry Management, Vol. 12 No. 3, pp. 215-233.

Colquitt, J. (2001), “On the dimensionality of organizational justice: a construct validation of a measure", Journal of Applied Psychology, Vol. 86 No. 3, pp. 386 - 400.

Darbi, M. and Karni, E. (1973), "Free competition and the optimal amount of fraud", Journal of Law and Economics, Vol. 16 No. 1, pp. $67-88$.

Dasu, S. and Rao, J. (1999), "Nature and determinants of customer expectations of service recovery in health care", Management in Health Care, Vol. 7 No. 4, pp. 32 - 50.

Davis, M. H. (1980), Empathy: A Social-Psychological Approach, Westview, Boulder, CO..

de Ruyter, K., Wetzels, M. and van Birgelen, M. (1999), "How do customers react to critical services encounters?: a cross-sectional perspective", Total Quality Management, Vol. 10 No. 8, pp. $1131-1145$.

de Ruyter, K. and Wetzels, M. (2000a), "Customer equity considerations in service recovery: a cross-industry perspective", International Journal of Service Industry Management, Vol. 11 No. 1, pp. 91 - 108.

de Ruyter, K. and Wetzels, M. (2000b), "The impact of perceived listening behavior in voiceto-voice service encounters", Journal of Service Research, Vol. 2 No. 3, pp. 276-284.

Deeter-Schmelz, D. R., Kennedy, K. N. and Goebel, D. J. (2002), "Understanding sales manager effectiveness - linking attributes to sales force values", Industrial Marketing Management, Vol. 31 No. 7, pp. 617-626.

Deeter-Schmelz, D. R., Goebel, D. J. and Kennedy, K. N. (2008), "What are the characteristics of an effective sales manager? An exploratory study comparing salesperson and sales manager perspectives", Journal of Personal Selling \& Sales Management, Vol. 28 No. 1, pp. 7-20.

Drain, M. (2001), "Quality improvement in primary care and the importance of patient perceptions", The Journal of Ambulatory Care Management, Vol. 24 No. 2, pp. 30 - 46.

Flanagan, J. C. (1954), “The critical incident technique”, Psychological Bulletin, Vol. 51 No. 4, pp. 327-358. 
Flint, D. J. (2006), "Innovation, symbolic interaction and customer valuing: thoughts stemming from a service-dominant logic of marketing", Marketing Theory, Vol. 6 No.3, pp. 349-362.

Fottler, M., Dickinson D., Ford, R., Bradley, K. and Johnson, L. (2006), “Comparing hospital staff and patient perceptions of customer service: A pilot study utilizing survey and focus group data", Health Services Management Research, Vol. 19 No.1, pp. 52 - 66.

Friele, R. and Sluijs, E. (2006), "Patient expectations of fair complaint handling in hospitals: empirical data”, BMC Health Services Research, Vol. 6 No. 106, pp. 1 - 9.

Gabbott, M. and Hogg, G. (1995), "Grounds for discrimination: establishing criteria for evaluating health services", The Service Industries Journal, Vol. 15 No. 1, pp. 90 - 101.

Gabbott, M. and Hogg, G. (1996), “The glory of stories: using critical incidents to understand service evaluation in the primary healthcare context," Journal of Marketing Management, Vol. 12 No. 6, pp. 493 - 503.

Garry, T. (2007), "Consumer sophistication and the role of emotion on satisfaction judgments within credence services", Journal of Consumer Behaviour, Vol. 6 No. 6, pp. 383 - 397.

Gengler, C.E. and Reynolds, T.J. (1993), "LADDERMAP: a software tool for analyzing laddering data" [Computer Software].

Gengler, C. E. and Reynolds, T. J. (1995), “Consumer understanding and advertising strategy: analysis and strategic translation of laddering data", Journal of Advertising Research, Vol. 35, pp. 19-33.

Gengler, C.E., Klenosky, D. and Mulvey, M. (1995), "Improving the graphic representation of means-end results", International Journal of Research in Marketing, Vol. 12 No. 3, pp. $245-256$.

Gengler, C. E, Mulvey, M. S. and Oglethorpe, J. E. (1999), "A means-end analysis of mothers' infant feeding choices", Journal of Public Policy \& Marketing, Vol. 18 No. 2, pp. 172-188.

Goodwin, C. and Verhage, B. (1989), "Role perceptions of services: a cross-cultural comparison with behavioral implications", Journal of Economic Psychology, Vol. 10 No. 4, pp. $383-397$.

Greenberg, J. (1987), “The college sophomore as guinea pig: setting the record straight”, The Academy of Management Review, Vol. 12 No. 1, pp. 157-159.

Gremler, D. D. (2004), “The critical incident technique in service research", Journal of Service Research, Vol. 7 No. 1, pp. 65 - 89. 
Grönroos, C. (1988), "Service quality: the six criteria of good perceived service quality", Review of Business, Vol. 9 No. 3, pp. 10 - 13.

Groth, M., Hennig-Thurau, T. and Walsh, G. (2009), "Customer reactions to emotional labor: the roles of employee acting strategies and customer detection accuracy", Academy of Management Journal, Vol. 52 No.5, pp. 958-974.

Gruber, T., Szmigin, I. and Voss, R. (2006), "The desired qualities of customer contact employees in complaint handling encounters", Journal of Marketing Management, Vol. 22 No. 5/6, pp. $619-642$.

Gruber, T., Szmigin, I. and Voss, R. (2009a), "Handling customer complaints effectively - a comparison of the value maps of female and male complainants", Managing Service Quality, Vol. 19 No. 6, pp. 636-656.

Gruber, T., Szmigin, I. and Voss, R. (2009b), "Developing a deeper understanding of attributes of effective customer contact employees in personal complaint handling encounters", Journal of Services Marketing, Vol. 23 No. 6, pp. 422-435.

Grunert, K. G., \& Grunert, S. C. (1995), "Measuring subjective meaning structures by the laddering method: theoretical considerations and methodological problems", International Journal of Research in Marketing, Vol. 12 No. 3, pp. 209-25.

Grunert, K.G., Beckmann, S. C. and Sørensen, E. (2001), "Means-end chains and laddering: an inventory of problems and an agenda for research", in Reynolds, T. J. and Olson, J. C. (Eds.), Understanding Consumer Decision Making - The Means-End Approach to Marketing and Advertising Strategy, Lawrence Erlbaum Associates, Mahwah, NJ, pp. 6390.

Gutman, J. (1982), “A means-end chain model based on consumer categorization processes”, Journal of Marketing, Vol. 46 No. 2, pp. 60 - 72.

Gutbezahl, C. and Haan, P. (2006), "Hospital service recovery", Journal of Hospital Marketing \& Public Relations, Vol. 16 No.1, pp. 3 - 14.

Guven-Uslu, P. (2005), "Benchmarking in health services", Benchmarking: An international Journal, Vol. 12 No. 4, pp. 293 - 309.

Hausman, A. (2004), "Modeling the patient-physician encounter: improving patient outcomes", Academy of Marketing Science Journal, Vol. 32 No. 4, pp. 403 - 417.

Henneberg, S. C., Gruber, T., Reppel, A., Ashnai, B. and Naudé, P. (2009), “Complaint management expectations: An online-laddering analysis of small versus large firms", Industrial Marketing Management, Vol. 38 No. 6, pp. 584-598. 
Hensel, J. and Baumgarten, S. (1988), "Managing patient perceptions of medical practice Service quality", Review of Business, Vol. 9 No. 3, pp. 23 - 26.

Hocutt, M., Bowers, M. and Donavan, D. (2006), "The art of service recovery: fact or fiction?” Journal of Services Marketing, Vol. 20 No. 3, pp. 199 - 207.

Hoffman, K.D., Kelley, S.W. and Rotalsky, H.M. (1995), "Tracking service failures and employee recovery efforts", Journal of Services Marketing, Vol. 9 No. 2, pp. 49 - 61.

Hogg, G, Laing, A. and Newholm, T. (2004), "Talking together: consumer communities and health care", Advances in Consumer Research, Vol. 31 No. 1, pp. 67 - 73.

Homburg, C. and Fuerst, A. (2005), "How organizational complaint handling drives customer loyalty: an analysis of the mechanistic and the organic approach", Journal of Marketing, Vol. 69 No. 3, pp. $95-114$.

Hui, M., Zhao, X., Fan, X. and Au, K. (2004), "When does the service process matter? A test of two competing theories", Journal of Consumer Research, Vol. 31 No. 2, pp. 465 - 475.

Hult, G. and Lukas, B. (1995), "Classifying health care offerings to gain strategic marketing insights", Journal of Services Marketing, Vol. 9 No. 2, pp. 36 - 48.

Jayanti, R. and Whipple, T. (2008), "Like me...like me not: the role of physician likeability on services evaluations", Journal of Marketing Theory and Practice, Vol. 16 No. 1, pp. 79 $-86$.

John, J., Gabbott, M. and Hogg, G. (1998), "The healthcare consumer", in Gabbott, M. and Hogg, G. (Eds.), Consumers and Service, John Wiley \& Sons Ltd, West Sussex, Chapter 8 , pp. $209-223$.

Johnston, R. and Michel, S. (2008), "Three outcomes of service recovery: customer recovery, process recovery and employee recovery", International Journal of Operations \& Production Management, Vol. 28 No. 1, pp. 79 - 99.

Karande, K., Magnini, V. and Tam, L. (2007), "Recovery voice and satisfaction after service failure: an experimental investigation of mediating and moderating factors", Journal of Service Research, Vol. 10 No. 2, pp. 187 - 203.

Kemppainen J., O'Brien L. and Corpuz B. (1998), “The behaviours of AIDS patients toward their nurses", International Journal of Nursing Studies, Vol. 35 No. 6, pp. 330 - 338.

Kenny, T. (1990), "Erosion of individuality in care of elderly people in hospital - an alternative approach", Journal of Advanced Nursing, Vol. 15 No. 5, pp. 571 - 576.

KeyNote - UK Healthcare Market (2005) (accessed: April 23 ${ }^{\text {rd }}, 2009$ ). 
Laing, A. and Hogg, G. (2002), "Political exhortation, patient expectation and professional execution: perspectives on the consumerization of health care", British Journal of Management, Vol. 13 No. 2, pp. 173 - 188.

Laing, A., Newholm, T. and Hogg, G. (2009), “Contradictory spaces: negotiating virtual spaces of consumption”, Journal of Service Management, Vol. 20 No. 2, pp. 227 - 245.

Laing, A., Newholm, T. and Hogg, G. (2005a), "Crisis of confidence: re-narrating the consumer-professional discourse", Advances in Consumer Research, Vol. 32 No. 1, pp. $514-521$.

Laing, A., Hogg, G and Winkelman, D. (2005b), “The impact of the internet on professional relationships: the case of health care", The Service Industries Journal, Vol. 25 No. 5, pp. $675-687$.

Laing, A., Hogg, G. and Winkelman, D. (2004), "Healthcare and the information revolution: re-configuring the healthcare service encounter", Health Services Management Research, Vol. 17 No. 3, pp. 188 - 199.

Lanseng, E. and Andreassen, T. (2007), "Electronic healthcare: a study of people's readiness and attitude toward performing self-diagnosis", International Journal of Service Industry Management, Vol. 18 No. 4, pp. $394-417$.

Leventhal, L. (2008), "The role of understanding customer expectations in aged care", International Journal of Health Care Quality Assurance, Vol. 21 No. 1, pp. 50 - 59.

Lewis, B. and Spyrakopoulos, S. (2001), "Service failures and recovery in retail banking: the customers' perspective", International Journal of Bank Marketing, Vol. 19 No. 1, pp. 37 47.

Lytle, R. and Mokwa, M. (1992), "Evaluating health care quality: the moderating role of outcomes", Journal of Health Care Marketing, Vol. 12 No. 1, pp. 4 - 14.

Macintosh, G. (2009), “The role of rapport in professional services: antecedents and outcomes", Journal of Services Marketing, Vol. 23 No. 2, pp. 71 - 79.

Magnini, V., Ford, J., Markowski, E. and Honeycutt, E. (2007), "The service recovery paradox: justifiable theory or smoldering myth?" Journal of Services Marketing, Vol. 21 No. 3, pp. $213-225$.

Malhotra, N. and Birks, D. (2006). "Marketing Research: An Applied Approach". Updated $2^{\text {nd }}$ European Edition. Essex: Pearson Education Limited.

Maslow, A. (1970), Motivation and Personality, $3^{\text {rd }}$ Edition, HarperCollins Publishers, New York. 
Mattila, A. (2004), "The impact of service failures on customer loyalty: the moderating role of affective commitment", International Journal of Service Industry Management, Vol. 15 No. 2, pp. $134-149$.

Mattila, A. S. and Enz, C. A. (2002), "The role of emotions in service encounters", Journal of Service Research, Vol. 4 No. 4, pp. 268-277.

Mattila, A. and Cranage, D. (2005), "The impact of choice on fairness in the context of service recovery", Journal of Services Marketing, Vol. 19 No. 5, pp. 271 - 279.

McCollough, M., Berry, L., Yadav, M. (2000), "An empirical investigation of customer satisfaction after service failure and recovery", Journal of Service Research, Vol. 3 No. 2 , pp. $121-137$.

McCollough, M. and Bharadwaj, S. (1992), “The service recovery paradox: an examination of consumer satisfaction in relation to disconfirmation, service quality, and attribution based theories, in Allen, C., Madden, T. , Shimp, T., Howell, R., Zinkhan, G., Heisley, D., Sernenik, R., Dickson, P., Zeithaml, P. and Jenkins, R. (Eds.), Marketing Theory and Applications, American Marketing Association, Chicago, IL.

Michel, S. (2001), “Analyzing service failures and recoveries: a process approach", International Journal of Service Industry Management, Vol. 12 No. 1, pp. 20 - 33.

Michel, S. and Meuter, M. (2008), “The service recovery paradox: true but overrated?", International Journal of Service Industry Management, Vol. 19 No. 4, pp. 441 - 457.

Michel, S., Bowen, D. and Johnston, R. (2009), "Why service recovery fails: tensions among customer, employee, and process perspectives”, Journal of Service Management, Vol. 20 No. 3, pp. $253-273$.

Moorman, C. and Matulich, E. (1993), “A model of consumers' preventive health behaviors: the role of health motivation and health ability", Journal of Consumer Research, Vol. 20 No. 2, pp. $208-228$.

Naidu, A. (2009), "Factors affecting patient satisfaction and healthcare quality", International Journal of Health Care Quality Assurance, Vol. 22 No. 4, pp. 366 - 381.

Newholm, T., Laing, A. and Hogg, G (2006), "Assumed empowerment: consuming professional services in the knowledge economy", European Journal of Marketing, Vol. 40 No. 9/10, pp. $994-1012$.

O'Connor, S., Schewchuck, R. and Carney, L. (1994), “The great gap: physicians' perceptions of patient service quality expectations fall short of reality", Journal of Health Care Marketing, Vol. 14 No. 2, pp. 32 - 39. 
O’Connor, S., Hann, T. and Schewchuck, R. (2000), "Perceptual gaps in understanding patient expectations for health care service quality", Health Care Management Review, Vol. 25 No. 2, pp. $7-23$.

Olson, J and Reynolds, T (2001), "The means-end approach to understanding Consumer Decision Making", in Reynolds, T. J. and Olson, J. C. (Eds.), Understanding Consumer Decision Making - The Means-End Approach to Marketing and Advertising Strategy, Lawrence Erlbaum Associates, Mahwah, NJ, chapter 1, pp. 3 - 20.

Padma, P., Rajendran, C. and Sai, L.P. (2009), "A conceptual framework of service quality in healthcare: perspectives of Indian patients and their attendants", Benchmarking: An International Journal, Vol. 16 No. 2, pp. 157 - 191.

Parker, S. K., \& Axtell, C. M. (2001), "Seeking another viewpoint: antecedents and outcomes of employee perspective taking", Academy of Management Journal, Vol. 44 No. 6, pp.1085-100.

Paul, M., Hennig-Thurau, T., Gremler, D., Gwinner, K. and Wiertz, C. (2009), "Toward a theory of repeat purchase drivers for consumer services", Journal of the Academy of Marketing Science, Vol. 37 No. 2, pp. 215 - 237.

Priluck, R. and Lala, V. (2009), “The impact of the recovery paradox on retailer-customer relationships", Managing Service Quality, Vol. 19 No. 1, pp. 42 - 59.

Ramsaran-Fowdar, R. (2008), "The relative importance of service dimensions in a healthcare setting”, International Journal of Health Care Quality Assurance, Vol. 21 No. 1, pp. 104 -124 .

Ramsey, R. P. and Sohi, W. S. (1997), "Listening to your Customers: the impact of perceived salesperson listening behavior on relationship outcomes", Journal of the Academy of Marketing Science, Vol. 25 No. 2, pp. 127-137.

Reidenbach R., and Sandifer-Smallwood, B. (1990), "Exploring perceptions of hospital operations by a modified SERVQUAL approach", Journal of Health Care Marketing, Vol. 10 No. 4, pp. 47 - 55.

Reynolds, T, Dethloff, C. and Westberg, S. (2001), "Advancements in laddering", in Reynolds, T. J. and Olson, J. C. (Eds.), Understanding Consumer Decision Making - The Means-End Approach to Marketing and Advertising Strategy, Lawrence Erlbaum Associates, Mahwah, NJ, chapter 4, pp. $91-118$.

Reynolds, T. and Gutman, J. (1988), "Laddering theory, method, analysis, and interpretation", Journal of Advertising Research, Vol. 28 No. 1, pp. 11 - 31. 
Rod, M. and Ashill, N. (2009), "Symptoms of burnout and service recovery performance: the influence of job resourcefulness", Managing Service Quality, Vol. 19 No. 1, pp. 60 - 84.

Rokeach, M. (1973), The Nature of Human Values, The Free Press, New York, NY.

Sage, G. (1991), "Customers and the NHS”, International Journal of Health Care Quality Assurance, Vol. 4 No. 3, pp. 11 - 14.

Sargeant, A. (2009), Marketing Management for Non-Profit Organizations, $3^{\text {nd }}$ Edition, Oxford University Press, Oxford.

Schneider, B. and Bowen, D. E. (1995), Winning the Service Game, Harvard Business School Press, Boston, MA.

Schweikhart, S., Strasser, S. and Kennedy, M. (1993), "Service recovery in health services organizations", Hospital \& Health Services Organizations, Vol. 38 No. 1, pp. 3 - 21.

Severt, D., Aiello, T., Elswick, S. and Cyr, C. (2008), "Hospitality in hospitals?" International Journal of Contemporary Hospitality Management, Vol. 20 No. 6, pp. 664 678.

Shemwell, D., Cronin, J. and Bullard, W. (1994), "Relational exchanges in services: an empirical investigation of ongoing customer service-provider relationships", International Journal of Service Industry Management, Vol. 5 No. 3, pp. 57 - 66.

Smith, A., Bolton, R., Wagner, J. (1999), “A model of customer satisfaction with service encounters involving failure and recovery”, Journal of Marketing Research, Vol. 36 No. 3, pp. $356-372$.

Spake, D. and Bishop, J. (2009), "The impact of perceived closeness on the differing roles of satisfaction, trust, commitment, and comfort on intention to remain with a physician", Health Marketing Quarterly, Vol. 26 No. 1, pp. $1-15$.

Spake, D., Beatty, S., Brockman, B. and Crutchfield, T. (2003), "Consumer comfort in service relationships”, Journal of Service Research, Vol. 5 No. 4, pp. 316 - 333.

Swanson, S. and Kelley, S. (2001), "Service recovery attributions and word- of-mouth intentions", European Journal of Marketing, Vol. 35 No. 1/2, pp. 194 - 211.

Taner, T. and Antony, J. (2006), "Comparing public and private hospital care service quality in Turkey", Leadership in Health Services, Vol. 19 No. 2, pp. I-X.

Tax, B. and Brown S. (1998), "Recovering and learning from service failure", Sloan Management Review, Vol. 40 No. 1, pp. 75 - 88.

Tax, B., Brown S. and Chandrashekaran, M. (1998), "Customer evaluations of service complaint experiences: implications for relationship marketing", Journal of Marketing, Vol. 62 No. 2, pp. $75-88$. 
Varela-Neira, C., Vázquez-Casielles, R. and Iglesias-Argüelles, V. (2008), "The influence of emotions on customer's cognitive evaluations and satisfaction in a service failure and recovery context”, The Service Industries Journal, Vol. 28 No. 4, pp. 497 - 512.

Vargo, S. L. (2008), "Customer integration and value creation: paradigmatic traps and perspectives", Journal of Service Research, Vol. 11 No. 2, pp. 211-215.

Vargo, S. L., and Lusch, R. F. (2004), "Evolving to a new dominant logic for marketing", Journal of Marketing, Vol. 68 No. 1, pp. 1-17.

Vargo, S. L., and Lusch, R. F. (2008a), "From goods to service(s): divergences and convergences of logics", Industrial Marketing Management, Vol. 37 No. 3, pp. 254-259.

Vargo, S. L., and Lusch, R. F. (2008b), "Why "service"?", Journal of the Academy of Marketing Science, Vol. 36 No. 1, pp. 25-38.

Vargo, S. L., and Lusch, R. F. (2008c), "Service-dominant logic: continuing the evolution", Journal of the Academy of Marketing Science, Vol. 36 No. 1, pp. 1-10.

Veludo-de-Oliveira, T., Akemi, A. and Cortez, M. (2006), "Laddering in the practice of marketing research: barriers and solutions", Qualitative Market Research: An International Journal, Vol. 9 No. 3, pp. 297 - 306.

Voss, R., Gruber, T. and Szmigin, I. (2007), "Service quality in higher education: the role of student expectations”, Journal of Business Research, Vol. 60 No. 9, pp. 949-959.

Wan, W. and Kamazuaraman, Hj (2009), "Service quality in a health care setting", International Journal of Health Care Quality Assurance, Vol. 22 No. 5, pp. 471 - 482.

Weun, S., Beatty, S. and Jones, M. (2004), "The impact of service failure severity on service recovery evaluations and post-recovery relationships", Journal of Services Marketing, Vol. 18 No. 2, pp. 133 - 146.

Wilde-Larsson, B. and Larsson, G. (2009). "Patients' views on quality of care and attitudes towards re-visiting the same provider", International Journal of Health Care Quality Assurance, Vol. 22 No. 6, pp. $600-611$.

Williams, S., Weinman, J., Dale, J. and Newman, S. (1995), "Patient expectations: what do primary care patients want from the GP and how far does meeting expectations affect patient satisfaction?" Family Practice, Vol. 12 No. 2, pp. 193 - 201.

Winsted, K. F. (2000), "Patient satisfaction with medical encounters: a cross-cultural perspective", International Journal of Service Industry Management, Vol. 11 No. 5, pp. $399-421$. 
Wirtz, J. and Mattila, A. (2004), "Consumer responses to compensation, speed of recovery and apology after a service failure", International Journal of Service Industry Management, Vol. 15 No. 2, pp. 150 - 166.

Wisniewski, M. and Wisniewski, H. (2005), "Measuring service quality in a colposcopy clinic", International Journal of Health Care Quality Assurance, Vol. 18 No. 3, pp. 217 228.

World Health Organization (WHO) (2008), “The World Health Report 2008: Primary Health Care: Now More than Ever”, Geneva, Switzerland: World Health Organization. Accessed online at [http://www.who.int/whr/2008/whr08_en.pdf] (accessed: June $9^{\text {th }}$, 2009).

Zeithaml, V., Berry, L. and Parasaruman, A. (1993), "The nature and determinants of customer expectations of service”, Journal of Academy of Marketing Science, Vol. 21 No. 1, pp. $1-12$. 
Figure 1. Hierarchical value map (recovery subgroup)

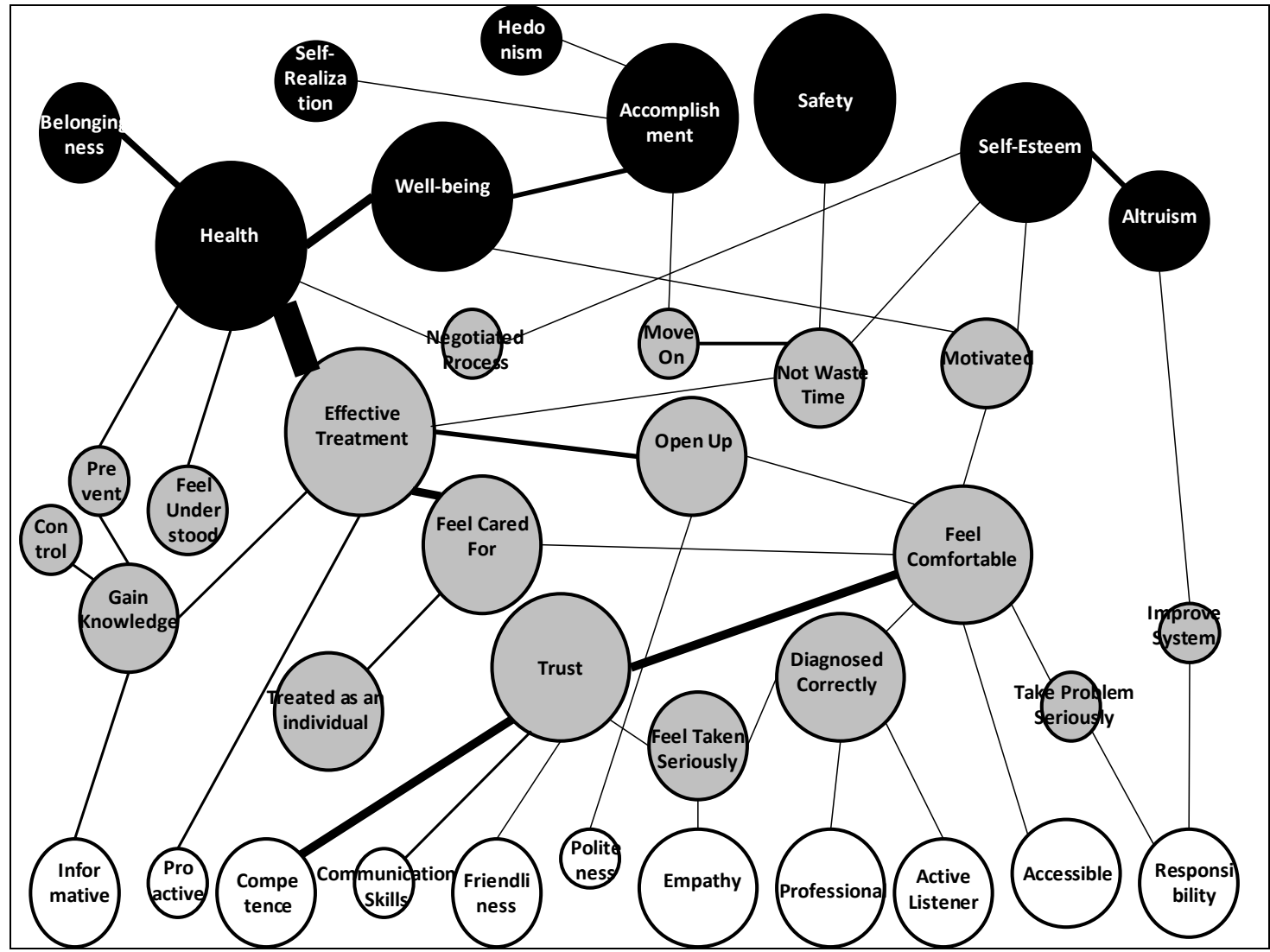

Note: White circles represent attributes, grey circles stand for consequences and black circles represent values. 
Figure 2. Hierarchical value map (normal subgroup)

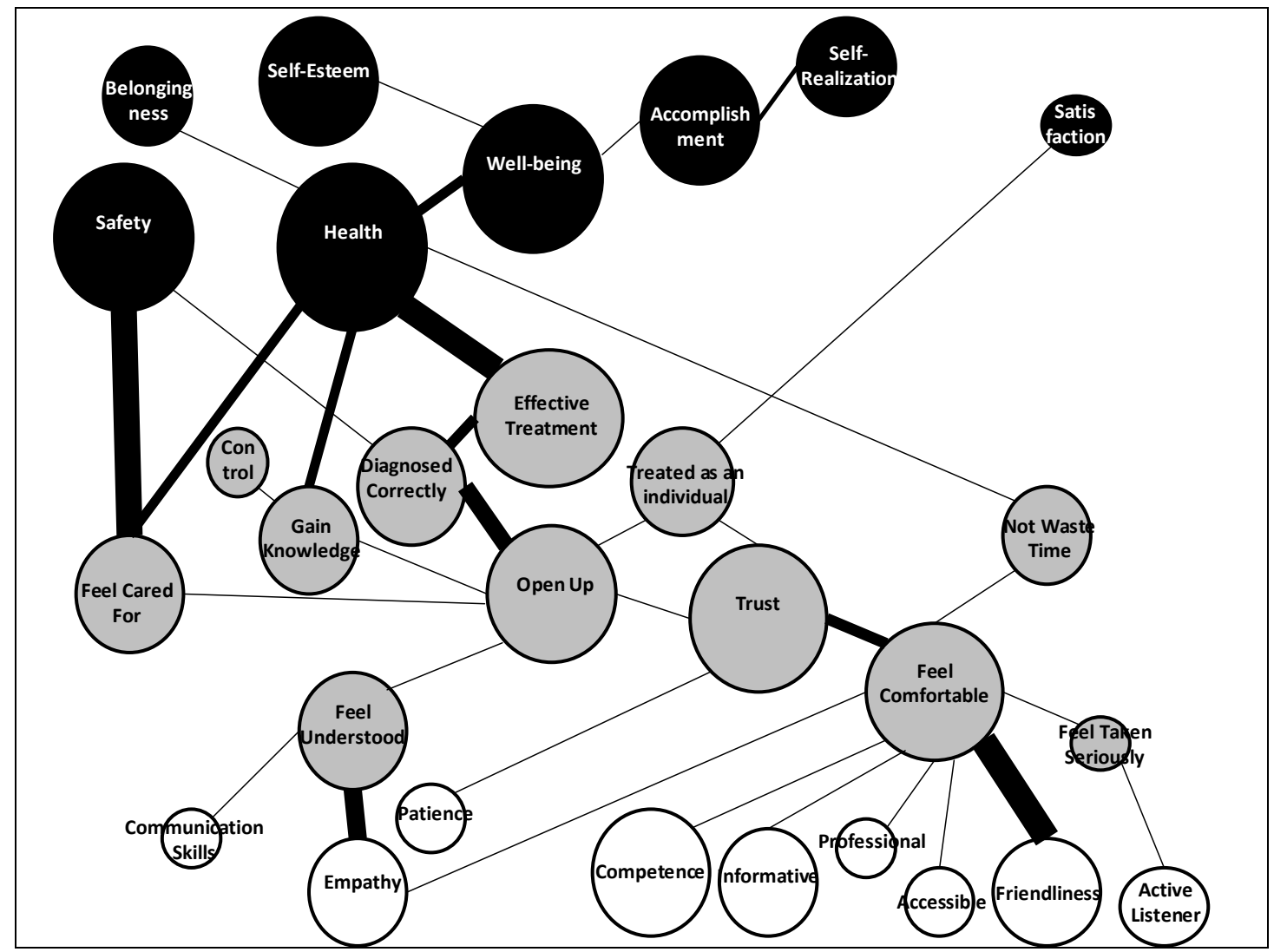

Note: White circles represent attributes, grey circles stand for consequences and black circles represent values. 
Table 1. Overview of attributes

\begin{tabular}{|c|c|c|c|}
\hline Name of Attribute & $\begin{array}{l}\text { Number of } \\
\text { times } \\
\text { mentioned } \\
\text { in Ladders } \\
\text { in Normal } \\
\text { Encounters }\end{array}$ & $\begin{array}{l}\text { Number of } \\
\text { times } \\
\text { mentioned } \\
\text { in Ladders } \\
\text { in Recovery } \\
\text { Encounters }\end{array}$ & Description \\
\hline Empathy & 28 & 24 & $\begin{array}{l}\text { GP should show that he is interested in the patient, show s/he cares } \\
\text { about the patient and is understanding of the feelings and background } \\
\text { of the patient. Patients perceive this quality from the GP when s/he } \\
\text { asks for the history and background of patients' ailments; tries to } \\
\text { relate to them; through body language and supportive remarks; shows } \\
\text { interest and sympathy as opposed of being bored and dismissive; and } \\
\text { acts in an accommodating and compassionate manner. }\end{array}$ \\
\hline Professionalism & 16 & 19 & $\begin{array}{l}\text { GP should behave professionally. This means s/he should do checks, } \\
\text { be conscious of time, be respectful, check and compare history, } \\
\text { follow code of conducts and ethics. }\end{array}$ \\
\hline Responsibility & 0 & 19 & $\begin{array}{l}\text { GP should be responsive, acknowledge and take responsibility for } \\
\text { actions, apologise and justify behaviour. }\end{array}$ \\
\hline Competence & 26 & 18 & $\begin{array}{l}\text { The GP should have knowledge, skill and experience. In order to } \\
\text { show competence, the GP should talk about his experience, the GP } \\
\text { should talk about their background, be well spoken of, have } \\
\text { confidence in his voice, be fast an accurate in his response, listen } \\
\text { carefully and make notes and be prudent. }\end{array}$ \\
\hline Informative & 24 & 16 & $\begin{array}{l}\text { GP should give feedback, health advice, willing to answer questions, } \\
\text { inform and discuss what is going on and the matter of illness of the } \\
\text { patients. }\end{array}$ \\
\hline Communication skills & 8 & 14 & $\begin{array}{l}\text { GP should have good communication skills, be able to interact, be a } \\
\text { good talker, have people skills, be easy to talk to and good eye } \\
\text { contact and good body language. }\end{array}$ \\
\hline Accessible & 7 & 13 & $\begin{array}{l}\text { Patients want their GP to be easy to reach, available, organized, easy } \\
\text { to contact and specially a better waiting period (quickness). }\end{array}$ \\
\hline Friendliness & 31 & 13 & $\begin{array}{l}\text { GP should be friendly. Respondents of this research perceive GP's } \\
\text { friendliness if s/he is warm, courteous, friendly and kind; breaks ice } \\
\text { to start a conversation; smiles; is open minded; welcoming; friendly } \\
\text { eyes; has nice personality; is polite. }\end{array}$ \\
\hline Active listener & 17 & 11 & Patients want their GP to listen actively to them. \\
\hline Politeness & 1 & 7 & GP should be polite. \\
\hline Proactive & 4 & 7 & GP should take initiative and action. \\
\hline Patience & 20 & 3 & $\begin{array}{l}\text { GP should have patience and take the time to talk and listen to the } \\
\text { patient. }\end{array}$ \\
\hline
\end{tabular}


Table 2. Overview of consequences

\begin{tabular}{|c|c|c|c|}
\hline $\begin{array}{l}\text { Name of } \\
\text { Consequence }\end{array}$ & $\begin{array}{l}\text { Number of } \\
\text { times } \\
\text { mentioned } \\
\text { in Ladders } \\
\text { in Normal } \\
\text { Encounters }\end{array}$ & $\begin{array}{l}\text { Number of } \\
\text { times } \\
\text { mentioned } \\
\text { in Ladders } \\
\text { in Recovery } \\
\text { Encounters }\end{array}$ & Description \\
\hline Feel Comfortable & 90 & 80 & $\begin{array}{l}\text { Patients want to feel comfortable, at ease, worry free, relieved and } \\
\text { assured that they are in good hands. }\end{array}$ \\
\hline Effective treatment & 67 & 75 & $\begin{array}{l}\text { GP can determine the best and most effective treatment for patients } \\
\text { in order to solve their problems. }\end{array}$ \\
\hline Trust & 67 & 57 & $\begin{array}{l}\text { Patients feel that they can rely on and have confidence in the } \\
\text { physician, his abilities, intentions and diagnosis. }\end{array}$ \\
\hline Feel cared for & 33 & 34 & $\begin{array}{l}\text { Patients want to feel that there is someone they can lean on and feel } \\
\text { taken care of. }\end{array}$ \\
\hline Diagnosed correctly & 25 & 33 & GP can determine the correct diagnosis. \\
\hline Open up & 74 & 25 & $\begin{array}{l}\text { Patients want to feel they can tell everything to the GP and express } \\
\text { freely. }\end{array}$ \\
\hline Gain Knowledge & 21 & 23 & $\begin{array}{l}\text { Patients want to learn and understand more about illnesses and their } \\
\text { condition; and get health advices. }\end{array}$ \\
\hline Treated as individual & 18 & 21 & $\begin{array}{l}\text { Patients want to feel like individuals, at the same level, related to } \\
\text { physicians, fairly and not like numbers. }\end{array}$ \\
\hline Feel taken seriously & 19 & 19 & Patients want to feel they are taken seriously and listened to. \\
\hline Not waste time & 14 & 17 & $\begin{array}{l}\text { Patients want to save time in the processes of seeing the GP and } \\
\text { getting cured. }\end{array}$ \\
\hline Feel Motivated & 5 & 13 & $\begin{array}{l}\text { By getting information, comfort and support, the patient will feel } \\
\text { more confident, with hope, more energy, be willing to cooperate } \\
\text { more optimistically and follow the treatment. }\end{array}$ \\
\hline $\begin{array}{l}\text { Take problem } \\
\text { seriously }\end{array}$ & 0 & 13 & $\begin{array}{l}\text { Patients want to have the impression that their problem is } \\
\text { acknowledged and taken seriously }\end{array}$ \\
\hline Move on & 4 & 12 & Patients want to take care of other things. \\
\hline Negotiated process & 2 & 9 & $\begin{array}{l}\text { Patients want to have an active role in the process of the treatment } \\
\text { decision. }\end{array}$ \\
\hline
\end{tabular}




\begin{tabular}{|l|r|r|l|} 
Control & 4 & 8 & $\begin{array}{l}\text { Patients want to be in control of what they are doing, decide or make } \\
\text { decisions by themselves and plan their lives. }\end{array}$ \\
\hline Feel understood & 39 & 8 & $\begin{array}{l}\text { Patients want to feel that the doctor understands them and their } \\
\text { needs; and feel accepted. }\end{array}$ \\
\hline Prevent & 3 & 8 & Patients want to prevent illnesses and stay healthy. \\
\hline Improve System & 0 & 7 & $\begin{array}{l}\text { Patients want to feel that their complaint and posterior solution will } \\
\text { contribute to the improvement of the system }\end{array}$ \\
\hline
\end{tabular}

\section{Table 3. Overview of values}

\begin{tabular}{|c|c|c|c|}
\hline Name of Consequence & $\begin{array}{l}\text { Number of } \\
\text { times } \\
\text { mentioned } \\
\text { in Ladders } \\
\text { in Normal } \\
\text { Encounters }\end{array}$ & $\begin{array}{l}\text { Number of } \\
\text { times } \\
\text { mentioned } \\
\text { in Ladders } \\
\text { in Recovery } \\
\text { Encounters }\end{array}$ & Description \\
\hline Health & 91 & 77 & Patients want to get healthy and cured. \\
\hline Well-being & 62 & 65 & $\begin{array}{l}\text { Patients feel good, better and want to live a long, } \\
\text { happy life. }\end{array}$ \\
\hline Accomplishment & 50 & 47 & $\begin{array}{l}\text { Patients want to carry on and achieve their goals } \\
\text { (study, work, success and others). }\end{array}$ \\
\hline Safety & 61 & 44 & Patients feel safe and secure. \\
\hline Self-esteem & 28 & 33 & $\begin{array}{l}\text { Patients feel better and happy about themselves, } \\
\text { unique, recognized, back to normal self, and } \\
\text { morally motivated. }\end{array}$ \\
\hline Hedonism & 11 & 25 & Patients want to enjoy life. \\
\hline Belongingness & 17 & 19 & $\begin{array}{l}\text { Patients feel accepted by others, not feel alone, } \\
\text { socialize and go back and care about family. }\end{array}$ \\
\hline Self Realization & 39 & 18 & $\begin{array}{l}\text { Patients want to make the best out of their lives } \\
\text { and feel self-realized. }\end{array}$ \\
\hline Altruism & 7 & 10 & $\begin{array}{l}\text { Patients care about the well-being and time of } \\
\text { others; and want to contribute to society with (1) } \\
\text { their efforts, (2) help and (3) improvement of the } \\
\text { system. }\end{array}$ \\
\hline Satisfaction & 8 & 3 & $\begin{array}{l}\text { Patients feel satisfied and that they got what they } \\
\text { expected. }\end{array}$ \\
\hline
\end{tabular}


Table 4. Overview of number and length of ladders

\begin{tabular}{|l|l|l|l|l|l|l|l|l|}
\hline & $\begin{array}{c}\text { Number } \\
\text { of } \\
\text { ladders }\end{array}$ & \multicolumn{3}{|c|}{$\begin{array}{c}\text { Number of ladders per } \\
\text { respondent }\end{array}$} & $\begin{array}{c}\text { Number } \\
\text { of } \\
\text { concepts } \\
\text { of } \\
\text { meaning } \\
\text { (A/C/V) }\end{array}$ & \multicolumn{2}{|c|}{$\begin{array}{c}\text { Number of concepts of } \\
\text { meaning per ladder } \\
\text { (=Length of ladder })\end{array}$} \\
\hline $\begin{array}{l}\text { Laddering } \\
\text { Interviews }\end{array}$ & 375 & 5 & 26 & 9.9 & 2167 & 3 & 10 & 5.7 \\
\hline
\end{tabular}

